\title{
COOPERATIVE LEARNING, ACADEMIC, AND SOCIAL GAIN: A STUDY OF MEDIATING ROLE OF TEACHER'S FEEDBACK
}

\author{
Najmonnisa Khan ${ }^{1}$, Farhan Uddin Raja ${ }^{2}$, Mirza Amin ul Haq ${ }^{3}$, Lubna Oad ${ }^{4 *}$, Rabia Aslam ${ }^{5}$ \\ ${ }^{1}$ Associate Professor, Shaheed Zulfiqar Ali Bhutto Institute of Science and Technology, Karachi, Pakistan; ${ }^{2}$ Assistant \\ Professor, Shaheed Zulfiqar Ali Bhutto Institute of Science and Technology, Karachi, Pakistan; ${ }^{3}$ Assistant Professor, Iqra \\ University, Karachi, Pakistan; ${ }^{4 * 5} \mathrm{Ph} . D$., Scholar, Shaheed Zulfiqar Ali Bhutto Institute of Science and Technology, Karachi, \\ Pakistan.

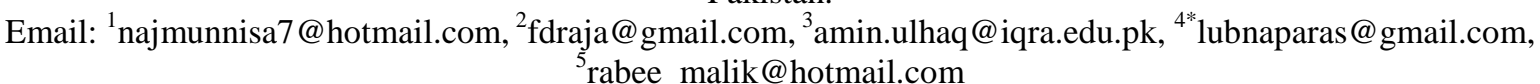

Article History: Received on $3^{\text {rd }}$ April 2021, Revised on $2^{\text {nd }}$ May 2021, Published on $6^{\text {th }}$ May 2021

\begin{abstract}
Purpose: The study aimed to investigate the scope of cooperative learning (CL) as an alternate of traditional teaching methods in Pakistani classrooms and to examine the direct and indirect relationship between CL and social \& academic gains through teacher feedback. The study also intended to survey students' opinions regarding the usefulness of the CL approach and to identify challenges that hindered its implementation at the tertiary level.
\end{abstract}

Methodology: This study was a cross-sectional and mixed-method (Concurrent Dominant Status (Quan+qual) research design). Qualitative data was collected through Focus Group Discussion (FGD) technique, while quantitative data was collected through a questionnaire. Data were analyzed with the help of mediation analysis using bootstrapping approach.

Results: Findings of Quantitative data analysis proved the significance of Cooperative Learning in terms of academic and social gains. Teachers` feedback had a significant mediating effect on the quality of students` group work. Qualitative data analysis revealed that students had a positive attitude towards the CL approach; however, students had few concerns regarding the group size, time, cohesion, etc. The study proposed using the CL method and teachers` feedback regularly during group assignments to improve students`academic and social gains.

Application of this Study: The findings of the study promote the implementation and use of cooperative learning at the tertiary level in different subjects to increase students` academic gain and social adjustment. As Pakistan is situated in East Asia so in Pakistani teachers should adopt this teaching methodology which supports collectivism rather than individualism.

The novelty of this study: The current study was unique by methodology as well as variables. The researcher adopted a mixed-method concurrent with Dominant Status (Quan+qual) research design. Researchers used teacher feedback as a mediating variable to assess CL's effect on learners' academic gains. Data was collected in three interims during the semester, and group assignments were given to students to intervene feedback with the CL.

Keywords: Cooperation, Interdependence, Accountability, Academic Gain, Social Gain, Feedback.

\section{INTRODUCTION}

The CL is one of the learners-centred teaching methods in which teacher encourages students of diverse abilities to work in small groups to improve their understanding of subject matter and encourage them to interact and cooperate to achieve a common goal (Chan, 2020; ). The effectiveness of CL is proved by many pieces of research concerning academic gain and social gain (Alzahrani, 2016; Mashhadi \& Gazorkhani, 2015; Nguyen et al., 2009; Reza, 2013; Tan et al., 2007; Tran \& Lewis, 2012; Siddique at al., 2020).

For this study, the CL is considered a teaching technique in which the teacher divides the class into small groups and assigns collective and structured home-based tasks with his/her interim feedback. During group interaction, diversity is appreciated and respected, helping students develop a positive relationship among group members (Sturz, Kleiner \& Fernandez, 2005; Nichols \& Sullivan, 2009; Green, Reid, \& Larson, 2012; Sharan, 2015). They learn communication skills and conflict resolution techniques (Goodwin, 1999).

Teaching and learning are in the process of evolution for centuries, however, the dominant status of the Lecture method still exists in Pakistani educational institutions specifically (Ali 1998; Jan 2013; Sajjad; Sarwar, 2001; Sultana \& Zaki, 2015; Siddiqui et al., 2020), and internationally in general (Loh,\& Ang, 2020). According to Najmonnisa (2013), the classroomlearning environment does not allow students to interact with each other; students sit in rows, facing the teacher and blackboard instead of facing each other to share and communicate knowledge to each other.

It is generally observed by the researchers of this study that there is a common misunderstanding among the teachers at the tertiary level who consider all types of group assignments or projects as part of the CL method. Since the main feature of CL is missing such as Positive interdependence, Social Skills, Individual Accountability, Group Reflection, Face-to-Face 
Interaction, therefore such understandings need to be addressed. In CL task, teachers` role is significant. He or she is supposed to perform the role of a facilitator (

Teacher's feedback and facilitation during group tasks/work is a prerequisite condition for CL. Group work is a prominent feature of CL tasks. Moreover, literature reports that group assignment is part of the formative assessment in which teacher's feedback on the performance of group members help them to reflect on their own and group learning, so students can control, monitor, and improve their learning pace and become independent learners (Nicol, \& Macfarlane-Dick, 2006). However, in the Pakistani context, teachers understanding and CL practices are very limited (Najmonnisa, 2013). Even in developed countries like Britain, Australia, America, CL is not effectively used (Jolliffe, 2015). Most of the time, teachers give students group assignments as a project and frequently use CL for these tasks without understanding the CL method (Najmonnisa, 2013). Teachers' facilitation in giving feedback is missing in such types of assignments as the assignments cannot be reviewed or revised. This observation is supported by Synnott (2016). Various research reports that in such group assignments, teachers only assign tasks without instructions, and no interim feedback is given ( $\mathrm{Hu} \& \mathrm{Choo}, 2015)$. Students are supposed to complete these projects until the end of the session outside of the classroom without teachers` facilitation. Students submit their report at/by the end of the session, following/followed by a group presentation, and then receive teachers`feedback.

Teachers should implement suitable methods of instruction and direct their students through the writing process to ensure producing a readable end product. The feedback provided by a teacher to students serves as one of the only forms of guiding them. Feedback is a central facet of the writing process, enabling students to acquire this skill (Azzioui, 2015). It motivates students to compose several writing drafts to ensure producing improved writing (Hamp-Lyons and Heasley cited in Azzioui, $\underline{2015})$.

Cooperative learning and teachers' feedback motivate students and enable them to reflect upon their work. Moreover, it helps students develop an acute perception of their writing and that of their peers. Therefore, it is suggested that Cooperative Learning's integration with teacher's feedback would improve the students` academic achievement and social gain. (Jolliffe, $\underline{2015)}$

Despite the usefulness of CL, very limited research has been conducted in Pakistan (Batool\&Perveen, 2012; Najmonnisa, 2013; 2014; 2016; Siddiqui et al., 2020) and internationally (Premo, Cavagnetto \& Davis, 2018; Makini, Barasa, \& Chemwei, 2020 to measure the level of capability of Cooperative Learning on academic accomplishment. However, according to the researcher's limited literature review, only one study conducted by Azzioui (2015) is found to investigate the relationship between CL, Teachers' feedback, and academic achievement.

The current study was unique by methodology as well as variables. The researcher adopted a mixed-method concurrent with Dominant Status (Quantitative + qualitative) research design. Researchers used teacher feedback as a mediating variable to assess Cooperative learning's effect on learners' academic gains. Despite the reported effectiveness of CL at the tertiary level (Vega \& Hederich, 2015), very few researches have been conducted to gauge feedback effectiveness (Evans, 2013). It was assumed from the study that CL is not adopted by the teachers of the tertiary level. The current study was intended to gauge the effectiveness of the CL method on learners`academic and social gains in the subjects of Sociology, Psychology, and writing research and mediating effects of teachers` feedback in the completion of group work.

\section{Research Questions}

1. How does CL affect students`academic achievement and social gain?

2. Does teachers' feedback mediate students`academic and social gain?

3. What are the student's and teachers' perceptions towards the use of CL and teachers' feedback at the tertiary level?

\section{LITERATURE REVIEW}

Due to the technological revolution, the whole world has become a global village (Thanh, Gillies \& Renshaw, 2008). People are interconnected and interdependent to achieve common and mutually beneficial goals. Globally, cooperation and teamwork are supported at all educational levels (Jolliffe, 2015; Slavin, 2015). For facilitating cooperation and interaction among students, teachers use various teaching methods in classrooms. CL is one of the teaching methods that characterize a situation in which teachers organize group activity in a structured manner to maximize learners' interpersonal and cognitive skills (Phiwpong \& Dennis, 2016). According to Johnson, Johnson \& Holubec (1998), CL includes the whole/complete range of learning exercises. Students are divided into small groups to work together on a mutual task in or out of class. The effectiveness of CL is validated through various researches as it has strong theoretical foundations (Johnson \& Johnson and Slavin cited in Buchs \& Butera, 2015). Literature also supports that CL is effective in learning gain in all academic aspects; it declines students' absenteeism, increases social unity, and accepts gender equity and diversity (Buchs \& Butera, 2015; Gillies, 2008; Premo, 2018; Slavin, 2015). 


\section{Theoretical Foundation}

Cooperative Learning (CL) has a strong foundation in several contemporary theoretical perspectives such as social constructivist, social cohesion, and motivational perspectives (Alzahrani, 2016; Makini, 2020). Social constructivists perceive the aim of education as the transformation of knowledge rather than the transmission of knowledge. The focus of activities is an interaction among the members of society (Sullivan, 1998). According to them, knowledge is socially constructed, and cognitive conflict promotes new learning through a constructivist interaction (Slavin, 2015). The teacher's role is very important; she promotes interaction in the classroom, and learning becomes meaningful in this way (Chebii, Wachanga, \& Anditi, 2018; Sharan, 2015).

According to motivational and social cohesion perspectives, students achieve their shared targets through collective efforts, as they are motivated to achieve the goal. Group members put their maximum effort into achieving set goals by helping each other. As group members are concerned about each other's success, they cooperate (Slavin, 1996; Karali \& Aydemir, 2018).

\section{Academic \& Social Gain for CL}

Findings of various researches support the benefits of CL in the areas of academic success and SS (Slavin, 1995, 1996, 2015; Azzioui, 2015; Mashhadi \& Gazorkhani, 2015; Phiwpong \& Dennis, 2016; Premo, 2018; Hendrawati \& Muhlisin, 2018).

\section{Teacher's Feedback}

Feedback is a vital element of formative assessment. It can be defined as the response of teacher towards "student's performance, attitude or behavior, at least where attitude or behavior impinges upon performance" (Dinham, 2005, p. 82)."Feedback is conceptualized as information provided by an agent regarding aspects of one's performance or understanding." (Hattie \& Timperley, 2007, p.81). Ferguson (2011) identified feedback as an acritical way to aid pupils in becoming autonomous learners who can "monitor, evaluate, and regulate their learning, allowing them to feed up and beyond graduation into professional practice."

The quality of teaching influences students' academic gain, and in this regard, teachers` feedback is a vital element (Hu \& Choo, 2016; Chaqmaqchee, 2015; Dinham, 2008; Shute, 2008; Paulus, 1999). Teacher's feedback is as essential as teacher's lectures and students` previous cognitive skills (Hyland, 2013). The difference of opinion was found while reviewing the literature. Some researchers consider feedback as a deciding item because of accomplishment. It is a kind of information about the quality of tasks provided by a more knowledgeable/skillful person (Pekrun et al., 2014) who can be a teacher, peer, parent, or guardian. The book or "self, experience concerning parts of one's accomplishment" can receive sometimes feedback (Hattie and Timperley, cited by Evans, 2013, p.71). For others, feedback is an essential component of learning (Orrell, 2006; Värlander, 2008; Cramp, 2011; Tucker \& Stronge (2005) stated that effective teachers provide timely feedback to their students and monitor their learning. Archer (2010) and Rosa \& Beijaardb (2013) support the same, according to the feedback given during the active learning process.

Based on the work of Ramaprasad (1983) and Sadler (2013), feedback is supposed to bridge the gap between the existing levels of performance and desired academic gain cited by Evans, 2013). Ovando (1994) suggests that teachers should give relevant, prompt, and systematic feedback. According to him, feedback should be delivered confidentially and respectably.

\section{Types of Feedback}

Lipnevich (2007) reported two types of feedback, intentional and unintentional. Teachers give both the kind of feedback however if he/she assigns task so she will provide purposeful feedback, which is an essential element of learning. Samuel (2013) reports that teachers give verbal and generic types of feedback on assignments and write comments on the assignment sheet. However, teachers give one on one feedback also on assignments, which is very time-consuming. Teachers have written feedback that is more effective than verbal feedback (White, 2008). Yoke et al. (2013) and Zhu, (2020) report various written feedback types such as "correcting errors, writing comments directly and indirectly." Few studies reported online feedback by teachers and peers, which is an effective feedback technique (Chaqmaqchee, 2015; Pinterest al., 2018).

\section{Theoretical Background}

Feedback is a process, which is being studied under/from the perspectives of behaviorist, cognitivist, and a socioconstructivist perspective. According to the behaviorist perspective, positive feedback plays a role in positive reinforcement. However, negative feedback is considered as punishment. Both reinforcement and punishment influence learning (Brookhart, 2008; Aslam \& Khan, 2020; Torrese et al., 2020).

According to the cognitivist point of view/perspective, feedback is directive in nature, which is supposed to tell students what to correct, and the teacher performs the role of an active expert who provides feedback on the performance of students (Bangert, Kulik, Kulik \& Morgan, 1991; Shute, 2008; Molin et al., 2020). On the contrary, according to the socioconstructivist perspective, feedback is considered as facilitation provided by a teacher or an expert who leads the learner 
through the Zone of proximal development and creates opportunities for them to reflect on their work from the perspective of others (Vygotsky cited in Hyland \& Hyland, 2006). The elaborative cognitive perspective states that students, who receive elaborated explanations from others, gain most from these activities (Webb cited in Slavin, 2015). Teachers` feedback, either verbal or written, empowers students to make their amendments, and with the help of teacher's feedback, they enhance their understanding without being told (Archer, 2010; Chaqmaqchee, 2015; Aslam \& Khan, 2020).

\section{Related Researches}

Black \& Wiliam (1998) conducted a meta-analysis of 250 studies. They found the positive influence of feedback on acquiring knowledge, skill development, and achievement in all content areas. They reported Elawar \& Corno's (1985) study in which the researchers measured the effect of feedback through experimental research. Researchers recruited more than 500 Venezuelan students from three schools, and 18 mathematics teachers were involved in the study. The study revealed that students who were given written feedback on their homework, such as pointing out particular mistakes with recommendations about rectifying those mistakes, performed well than students whose assignments were only marked without receiving any feedback.

Ismail, Maulan \& Hasan (2008) conducted an experimental study to determine the effect of teacher's feedback on students' writing skills. During the experiment, students were given three topics to write essays/on one. Students were asked to write an essay during the class period and then submit it to their teachers, and after one week, teachers returned their assignments with feedback. Students resubmitted their essays after incorporating the given feedback. "Each essay was given one of these feedback types; content feedback or endnote feedback respectively/alternatively. A score/number for the content, organization, and language was given/awarded for each of the essays based on the analytic scale" (pp 45). The study's findings revealed that feedback provided on students` assignments was found to be effective that helped students improve their assignments with the help of self-revision. A significant difference was observed in the first and second drafts of students` written essays when content feedback was given to them, and improvement in the correct use of grammar was also observed.

Reugg (2015) conducted an exploratory study to investigate the effect of the feedback given during and at the end of written assignments. Teachers provided feedback to two groups of students throughout the year. The experimental group was assigned interim feedback during the task, and they revised their drafts accordingly, whereas the control group was given feedback at the end of the task. The performance/result/score of both the groups was compared based on Mann-Whitney $U$ test. ANOVA was used to compare the performance of students. It was found that the experimental group performed significantly better than the control group.

Therefore, we hypothesize that if students receive effective teacher's feedback while doing group assignment; their quality of work would be enhanced

\section{Hypotheses}

$\mathbf{H}_{1}$ : There is a significant direct relationship between cooperative learning and social gain.

$\mathbf{H}_{2}$ : Teacher feedback mediates the relation between cooperative learning and social gain.

$\mathbf{H}_{3}$ : There is a direct relationship between cooperative learning and academic gain.

$\mathbf{H}_{4}$ : Teacher feedback mediates the relation between cooperative learning and academic gain.

\section{Research Model}

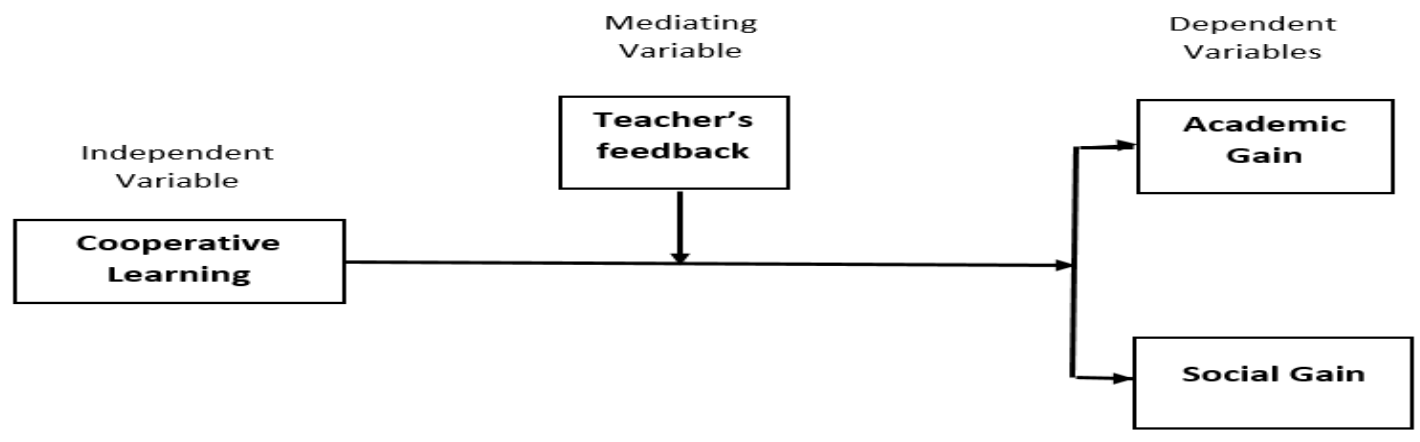

Figure 1: Conceptual Model of the Study

Source: Authors conceptualization 


\section{METHODOLOGY}

This study is based on the perception that teachers do not give interim feedback while giving home-based CL assignments at the tertiary level (Evans, 2013). However, the effectiveness of CL and the importance of interim feedback in CL task has been proved by numerous researches (Herrmann, 2013). The current study aimed to examine the direct and indirect relationship between cooperative learning and social \& academic gains through teacher feedback at the tertiary level. In the present study cooperative learning method is the independent variable, the teacher's feedback is the mediator, and social and academic gains are two dependent variables. Moreover, to gauge the CL method's effectiveness on learners` academic and social gains in the subject of Sociology, Psychology and Writing Research Report and mediating effects of teachers` feedback in the successful completion of group work. Researchers adopted a mixed-method approach, contemporary design with dominant status (Quan + qual), to collect quantitative and qualitative data (Greene, 2007; Creswell \& Plano Clark, 2011). Qualitative and quantitative data were collected concurrently. A Survey technique was adopted to collect the data.

Students of tertiary level constitute the research population. They are of between age group of 18-22 years old (Kaufman, Sutow \& Dunn, 1997). The researcher selected eight sections of BBA $1^{\text {st }}$ semester and four sections of BBA $2^{\text {nd }}$ Semester from a private sector university by using the convenience sampling technique. Students of Sociology, Psychology, and Writing Research Report courses were selected as research subjects. The sample size was 32 students for qualitative data collection (derived from the 538 students) and 538 students for quantitative data. The researcher collected qualitative and quantitative data concurrently. For qualitative data, five focus group discussions (FGDs) were conducted with 32 selected students. The aim of FGDs s was to validate, contradict, or enhance findings from the experiment. For quantitative data, 600 questionnaires were distributed to students to gauge the effectiveness of CL and the mediating effect of teachers` feedback, whereas 538 filled questionnaires were returned. The response rate was $89.8 \%$. (89.66\%) The sample comprised of $48 \%$ male and $52 \%$ female students, and their age group is between 18 and 22 years.

After reviewing the literature, the researcher adopted the scale of CL from Brown (2008), the scale of social gain adapted from Waksman Social Skills Rating Scale (Waksman, 1985) for teacher feedback and students` concerns regarding CL, the scale was adapted from Nunez et al., (2015). All the questionnaire items were designed for a Likert scale response using a five-interval scale from strongly agree to disagree strongly. The reliability score of the questionnaire was 0.896 (Sekaran, 2006). This was above 0.7. In this way, the instrument was viewed as reliable for use in the study.

\section{Data Analysis Technique}

To measure the CL method's effectiveness on the academic and social gain of students, the researcher adopted quantitative and qualitative data analysis techniques, for qualitative data researcher used the thematic analysis technique (Braun \& Clarke, 2006). In thematic analysis, the researcher utilized both the first words discussed by respondents in citations to precisely display the participants` view and the researchers` portrayal of the occasions. To test the model, mediation analysis was performed using bootstrapping approach recommended by Preacher \& Heyes (2004) using process macro in SPSS developed by Heyes (2013).

\section{Data Collection Procedure}

Initially, the researcher selected a private sector university and took informed consents of dean faculty of business administration and teachers of Psychology, Sociology and Writing Research Report of Bachelor of Business Administration (BBA). Before introducing the CL technique in the classroom, the researcher conducted CL workshops to understand the method. During the semester, teachers planned three home-based group assignments with researchers' help and with clear instructions for each assignment. Two feedback sessions were kept for each assignment. The group size was kept as small as 4-5 students. Groups were diverse for abilities and based on their previous semester's performance. Students were assigned different roles during group tasks, such as group leader, mediator, writer, etc. Feedback was given using the procedure suggested by Hattie \& Timperley, cited in Brookhart, (2008). According to the proposed model, teachers gave feedback at four level

(1) feedback about the task (such as feedback about whether answers were right or wrong or directions to get more information), (2) feedback about the processing of the task (such as feedback about strategies used or strategies that could be used), (3) feedback about self-regulation (such as feedback about student self-evaluation or self-confidence), and (4) feedback about the student as a person (such as pronouncements that a student is "good" or "smart")" (p.4).

At the end of the semester, the researcher distributed questionnaires and conducted FGDs to collect the data simultaneously. The researchers collected data.

\section{DATA ANALYSIS}

Research question 1: What are the concerns of students regarding CL? 
Table 1: Concerns of students relating to CL

\begin{tabular}{llllll}
\hline Statement & $\mathbf{1}$ & $\mathbf{2}$ & $\mathbf{3}$ & $\mathbf{4}$ & $\mathbf{5}$ \\
\hline 1. Maximum group size should be between 4-5 & 220 & 194 & 80 & 30 & 14 \\
\hline 2. Team learning/ Group work should be encouraged/continued & 232 & 184 & 60 & 36 & 26 \\
\hline 3. Difficult getting members to actively participate in tasks & 16 & 36 & 98 & 226 & 162 \\
\hline 4. Waste of time explaining things to other & 22 & 34 & 70 & 200 & 212 \\
\hline
\end{tabular}

Note $1=$ Strongly Agree, 2 = Agree, $3=$ Neutral, $4=$ Disagree, $5=$ Strongly disagree

Group size matters a lot for the effective completion of the task. According to the data set, $77 \%$ of students believe that the maximum group size should be between 4 to 5 students. $8.1 \%$ of students showed disagreement on this group size, and $14.9 \%$ of students have a neutral opinion. Students have a positive perception about CL, and $77.3 \%$ of students showed agreement to continue CL activities; however, $11.5 \%$ of students showed disagreement, whereas $11.2 \%$ of students are of the neutral opinion. The majority of students, i.e., $72.1 \%$ of them, do not perceive any difficulty getting group members actively participating in the task. In comparison, 9.7\% consider it difficult, whereas $18.2 \%$ are neutral as positive interdependence is a significant characteristic of CL, so students are responsible for each other's learning. Data set reveals that $76.6 \%$ of students showed disagreement with this statement that explaining concepts to others is a waste of time. However, $10.4 \%$ of students consider it a waste of time, and 13\% have a neutral opinion. It shows that students are motivated to cooperate and do not consider it a waste of time.

\section{Findings from FGDs}

\section{Perceptions of Students Regarding CL}

The findings of the FGDs reveal that students have positive perceptions about the effectiveness of CL as a teaching method, which might give long-lasting learning experiences in terms of academic and social gains (Brown, 2008). Few sample statements are listed below:

Note: (Extract from focus group discussions (FGDs) translated in English).

- I appreciated a lot working in a group.

- Learning in a group is more valuable than learning alone

- We had a lot of fun during group work.

- It made me surer, on the off chance that I don't know anything so that I can ask my companion.

- There were a couple of arguments among group members; however, we resolved the issues quickly without being passionate.

Most of the students were having a favorable opinion regarding CL; according to them, CL increases their academic and social skills (Cecchini et al., 2020). Working together enables them to utilize social skills in incompatible circumstances (Korkmaz \& Oztürk, 2020).

\section{Hypotheses Testing}

The purpose of the current study was to examine the direct and indirect relationship between cooperative learning and social $\&$ academic gain through teacher's feedback. In the current analysis, a cooperative learning strategy is an independent variable, teacher's feedback is the mediator, and social and academic gains are two dependent variables. To test the model, mediation analysis was performed using bootstrapping approach recommended by Preacher \& Heyes (2004) using process macro in SPSS developed by Heyes; (2013). The following hypothesis was tested in this research:

$\mathbf{H}_{\mathbf{1}}$ : There is a significant direct relationship between cooperative learning and social gain.

$\mathbf{H}_{2}$ : Teacher feedback mediates the relation between cooperative learning and social gain.

$\mathbf{H}_{3}$ : There is a direct relationship between cooperative learning and academic gain.

$\mathbf{H}_{4}$ : Teacher feedback mediates the relation between cooperative learning and academic gain.

In Table 2, two mediation models were developed and tested using the Process Macro approach in SPSS as suggested by Heyes (2013). The reason for developing two separate models was because of the limitation of the macro - i.e., it can accommodate only one dependent variable in the analysis at a particular time. In the first model, where the dependent variable was social gain, the $\mathrm{F}$ test value was 60.596 , $\mathrm{p}$-value $<0.01$ that was significant. Therefore, the relationship between 
the variables was not due to a chance. Moreover, R2 represents around 10\% impact of all the independent variables on the dependent variable.

As far as model 1 is concerned, the direct relationship between cooperative learning and social gain was found to be insignificant - i.e., beta value- $.0369, \mathrm{p}<0.01$. Therefore, the hypothesis that "There is a significant direct relationship between cooperative learning and social gain" was rejected. On the other hand, the indirect relationship between cooperative learning and social gain through teacher's feedback was significant with effect size $.3960, p<0.10$. This means that the hypothesis, "Teacher's feedback mediates the relation between cooperative learning and social gain," was accepted. Furthermore, the total effect was also significant, with an effect size of 0.3590. p <0.01, which concludes that teacher feedback fully mediates the relationship between cooperative learning and social gain.

Table 2: Mediation Analysis Results

\begin{tabular}{lllll}
\hline \multirow{2}{*}{ Model } & \multicolumn{2}{l}{$\begin{array}{l}\text { Social Gain } \\
\text { (Mediator }=\text { Teacher's Feedback) }\end{array}$} & \multicolumn{2}{l}{ Academic Gain } \\
\cline { 2 - 5 } & $\mathbf{B}$ & SE & B & SE \\
\hline Direct Effects & & & & 0.0537 \\
\hline Co-operative Learning & -0.0369 & 0.077 & $.6047^{* * *}$ & \\
\hline Indirect Effects & & & & 0.0699 \\
\hline Co-operative Learning & $.3960^{*}$ & 0.063 & 0.5348 & \\
\hline Total Effects & & & & 0.0311 \\
\hline Co-operative Learning & $.3590^{* * *}$ & 0.046 & $.0699^{* * *}$ & \\
\hline $\mathrm{R}^{2}$ & 0.1016 & & 0.4136 & \\
\hline F test & $60.596^{* * *}$ & & $378.016^{* * *}$ & \\
\hline
\end{tabular}

***. Correlation is significant at the 0.01 level (2-tailed).

*. Correlation is significant at the 0.10 level (2-tailed).

In model 2, the dependent variable was academic gain, where the $\mathrm{F}$ statistic was significant as the $\mathrm{F}$ value is $738.016 . \mathrm{p}<$ 0.01. In addition to that, $\mathrm{R} 2$ is approx. $41 \%$ implies a sufficient overall influence of all the variables on the dependent variable. In this particular model, a direct relationship between cooperative learning is significantly associated with academic gain with an effect size of 0.6047. Therefore, the hypothesis, "there is a direct relationship between cooperative learning and academic gain was accepted. Furthermore, the indirect relation between cooperative learning and academic gain through teacher's feedback was insignificant as the indirect effect size .5348 was not significant, i.e., a p-value less than 0.5. It implied that the hypothesis, "teacher's feedback mediates the relation between cooperative learning and academic gain," was rejected.

The overall crux is that teacher feedback is the main reason for the relationship between cooperative learning and social gain - i.e., if there is no feedback from the teacher, cooperative learning is not the right strategy for students' social learning. On the other hand, in the second variable, cooperative learning is a helpful strategy for academic gain regardless of its feedback.

\section{DISCUSSION AND RECOMMENDATIONS}

Findings of the research is inconsistency with the findings of the studies which reported the effectiveness of CL in relation to academic gain (Goodwin, 1999; Tan, Sharan \& Lee, (2007); Thanh-Pham (2008); Nguyen (2009); Tran \& Lewis, (2012); Tran \& Lewis (2012); Ebrahim (2012); Reza, (2013); Lau, Chong \&Wong (2014); Paul \& Ray, (2014); Inuwa, (2015); Garcha \& Kumar (2015); Mashhadi \& Gazorkhani (2015); Phiwpong \& Dennis, (2016). The findings support the theoretical perspectives of social constructivism. According to social constructivism, knowledge is built socially, so CL facilitates learning in an asocial environment (Johnson \& Johnson, 2006; Slavin, 2015; Makini, 2020), considering that CL could be an approach that gives the best result in scholarly accomplishment students as compared to traditional group assignments. Findings of focus group discussions also support quantitative data findings as students showed positive perceptions towards CL. They perceived it helpful in their academic gain and motivation towards learning. They said that they enjoyed working in groups. Students` performances and responses show that cooperative learning improved their level of academic gain.

In contrast, the mediating role of teacher`s feedback in terms of increasing academic gain is proved insignificant, which is contradicting the findings of previous researches (Wiliam, 1998; Paulus, 1999; Dinham, 2008; Shute, 2008; Ismail et al., 2008; Chaqmaqchee, 2015; Black \& Reugg, 2015; $\mathrm{Hu} \& \mathrm{Choo,2016).} \mathrm{Findings} \mathrm{related} \mathrm{to} \mathrm{CL's} \mathrm{effects} \mathrm{in} \mathrm{enhancing} \mathrm{social}$ gain are not consistent with the previous research and not supporting the social cohesion perspective. Results show that there is no direct relationship between CL and social gain. However, the role of teachers feedback as a mediator proved to be effective for gaining social skills, which are not discussed in mostly reviewed researches but only in Ross (1995). This finding can be considered a significant contribution in the field of educational research. 


\section{CONCLUSION}

It can be concluded that CL can be adopted as an alternative to the traditional teaching method at the tertiary level. Teachers feedback plays an essential role in increasing group cohesion. Researchers have advocated the implementation and use of cooperative learning at the tertiary level in different subjects to increase students` academic gain and social adjustment. As Pakistan is situated in East Asia so in Pakistani schools' teacher should adopt a teaching methodology which supports collectivism rather individualism. Researchers recommend conducting future researches to explore the direct and indirect relationship between teachers` feedback and social and academic gain. Future researchers may study the significance of CL in different subjects and across gender.

\section{LIMITATION OF THE STUDY}

In this study, data was collected from the students of Private Sector University with the help of convenience sampling technique. Moreover, researchers selected participants from Sociology, Psychology, and Writing Research Report courses by using the convenience sampling technique. Therefore, it is recommended that in future research, respondents of public sector universities should also be included to collect the data. It is suggested that students may be selected with the help of a stratified random sampling technique and respondents from courses other than social sciences may be selected to collect the data.

\section{CONTRIBUTION OF AUTHORS}

Prof. Dr. Najmonnisa Khan contributed majorly to designing methodology and developing research tools moreover, she also contributed to conceptualizing the introduction and literature review of this study.

Farhan Uddin Raja: He also contributed to conceptualizing the introduction of this study.

Mirza Amin Ul Haq: He helped in the analysis and interpretation of data.

Lubna Oad contributed to developing discussions and conclusion, recommendation, limitations of the study.

Rabia Aslam contributed to the data analysis section, generate themes, interpret findings, and future research directions.

\section{REFERENCES}

1. Ahmed, Z., \& Mahmood, N. (2010). Effects of Cooperative Learning vs. Traditional Instruction on Prospective Teachers' Learning Experience and Achievement. Journal of Faculty of Educational Sciences, 43(1), 11-164. Retrieved from http://dergiler.ankara.edu.tr/dergiler/40/1342/15555.pdf

2. Ali, T. (1998). Ali, T. (1998). Use of inquiry in science classroom teaching in Pakistani middle schools (Unpublished master's dissertation). Aga Khan University, Karachi, Pakistan.

3. Alzahrani, I. (2016). The role of constructivist learning theory and collaborative learning environment on Wiki classrooms and relationship between them. World Academy of Science, Engineering and Technology International Journal of Social, Behavioral, Educational, Economic, Business and Industrial Engineering, 10(3), 882-885.

4. Ansari, J. A. N., \& Khan, N. A. (2020). Exploring the role of social media in collaborative learning the new domain of learning. Smart Learning Environments, 7(1), 1-16. https://doi.org/10.1186/s40561-020-00118-7

5. Apple, M. W. (2006). Understanding and interrupting neo-liberalism and neo-conservatism in education. Pedagogies: An International Journal, 1(1), 21-26. https://doi.org/10.1207/s15544818ped0101 4

6. Aslam, R., \& Khan, N. (2020). Constructive feedback and Students' academic achievement: a theoretical framework. New Horizons, 14(2), 175.

7. Archer, J. C. (2010). State of the science in health professional education: Effective feedback. Medical Education, 44, 101-108. https://doi.org/10.1111/j.1365-2923.2009.03546.x

8. Azzioui, A. (2015). The effect of LT cooperative learning model and teacher`s feedback on second-year EFL students`writing. Expressions, 102-110.

9. Ballantine, J. \&Larres, P. M. (2007). Cooperative learning: a pedagogy to improve students' generic skills? Education + Training, 49(2), 126 - 137. https://doi.org/10.1108/00400910710739487

10. Bangert-Drowns, R. L. ;Kulik, C. L. ; Kulik, J. A. \& Morgan, M. T. (1991). The instructional effect of feedback in test-like events. Review of Educational Research, 61(2), 213-238. https://doi.org/10.3102/00346543061002213

11. Black, P., \&Wiliam, D. (1998). Assessment and classroom learning. Assessment in Education: Principles, Policy \& Practice, 5(1), 7-74. https://doi.org/10.1080/0969595980050102

12. Blatchford, P., Kutnick, P., Baines, E. \& Galton, M. (2003). Toward a social pedagogy of classroom group work. International Journal of Educational Research, 39, 153-172. https://doi.org/10.1016/S0883-0355(03)00078-8

13. Braun, V. \& Clarke, V. (2006). Using thematic analysis in psychology. Qualitative Research in Psychology, 3(2), 77-101. https://doi.org/10.1191/1478088706qp063oa 
14. Brookhart, S. M. (2008). How to give effective feedback to your students. Virginia: Association for Supervision and Curriculum Development Association (ASCD).

15. Brown, F.A. (2008). Collaborative Learning in the EAP Classroom: Students' Perceptions on English for Specific Purposes World. Online Journal for Teachers, Vol.7(1) 1-18.

16. Buchs, C., \& Butera, F. (2015). Cooperative learning and social skills development. Collaborative learning: Developments in Research and Practice, 201-217. Retrieved from serval.unil.ch: https://serval.unil.ch/resource/ser val:BIB A593B6B4EF0F.P001/REF

17. Casey, A., Goodyear, V. A., \& Dyson, B. P. (2015). Model fidelity and students' responses to an authenticated unit of cooperative learning. Journal of Teaching in Physical Education, 34(4), 642-660. https://doi.org/10.11 23/itpe.2013-0227

18. Cecchini, J. A., Fernandez-Rio, J., Mendez-Gimenez, A., Gonzalez, C., Sanchez-Martínez, B., \& Carriedo, A. (2020). High versus low-structured cooperative learning. Effects on prospective teachers' regulation dominance, motivation, content knowledge and responsibility. European Journal of Teacher Education, 1-16. https://doi.org/10.1080/02619768.2020.1774548

19. Chan, M. (2020). A multilevel SEM study of classroom talk on cooperative learning and academic achievement: Does cooperative scaffolding matter? International Journal of Educational Research, 101, 101564.Chaqmaqchee, Z. A. (2015). Teacher's attitudes toward a different approaches to providing feedback to students in higher education. Journal of Education and Practice, 6(2), 150-162. https://doi.org/10.1016/j.ijer.2020.101564

20. Chaqmaqchee, Z. A. (2015). Teacher's attitude into different approach to providing feedback to students in higher education. Journal of Education and Practice, 6(2), 150-162.

21. Chebii, R., Wachanga, S. W., \& Anditi, Z. O. (2018). Effects of Cooperative E-Learning Approach on Students' Chemistry Achievement in Koibatek Sub-County, Kenya. Creative Education, 09(12), 1872-1880. https://doi.org/1 0.4236/ce.2018.912137

22. Chebii, R., Wachanga, S. W., \& Anditi, Z. O. (2018). Effects of Cooperative E-Learning Approach on Students' Chemistry Achievement in Koibatek Sub-County, Kenya. Creative Education, 9(12), 1872. https://doi.org/10 $.4236 /$ ce. 2018.912137

23. Cramp, A. (2011). Developing first-year engagement with written feedback. Active Learning in Higher Education, 12(2), 113-124. https://doi.org/10.1177/1469787411402484

24. Creswell, J. W., \& Clark, V. L. P. (2017). Designing and conducting mixed methods research. Sage publications.

25. Dinham, S. (2008). Powerful teacher feedback. Synergy, 6(2), 35-38.

26. Dinham, S., \& Rowe, K. (2009). Teaching and learning in middle schooling: A review of the literature. Wellington, New Zealand: Ministry of Education.

27. Ebrahim, A. (2012). The effect of cooperative learning strategies on elementary students 'science achievement and social skills in Kuwait. International Journal of Science and Mathematics Education, 10(2), 293-314. https://doi.org/10.1007/s10763-011-9293-0

28. Evans, C. (2013). Making sense of assessment feedback in higher education. Review of Educational Research, 83(1), 70-120. https://doi.org/10.3102/0034654312474350

29. Esiobu, G. O. (2011). Achieving gender equity in science class: Shift from competition to cooperative learning. Multicultural Education \& Technology Journal. https://doi.org/10.1108/17504971111185081

30. Elawar, M. C., \& Corno, L. (1985). A factorial experiment in teachers' written feedback on student homework: Changing teacher behavior a little rather than a lot. Journal of educational psychology,77(2), 162. https://doi.org/10.1037/0022-0663.77.2.162

31. Ferguson, P. (2011). Student perceptions of quality feedback in teacher education. Assessment \& Evaluation in Higher Education, 36, 51-62. https://doi.org/10.1080/02602930903197883

32. Freudenberg, B., Brimble, M., \& Cameron, C. (2011). WIL and generic skill development: The development of business students' generic skills through work-integrated learning.Asia-Pacific Journal of Cooperative Education, 12(2), 79-93.

33. Garcha, P. S., \& Kumar, K. (2015). Effectiveness of Cooperative Learning on Critical Thinking Dispositions of Secondary School Students. Issues and Ideas in Education, 3(1), 41-62. https://doi.org/10.15415/iie.2015.31005

34. Gillies, R. M. (2008). The effects of cooperative learning on junior high school students' behaviors, discourse, and learning during a science-based learning activity. School Psychology International, 29(3), 328-347. https://doi.org/10.1177/0143034308093673

35. Gillies, R. M., \& Boyle, M. (2011). Teachers' reflections of cooperative learning (CL): a two-year follow-up. Teaching Education, 22(1), 63-78. https://doi.org/10.1080/10476210.2010.538045

36. Goodwin, M. W. (1999). Cooperative Learning and Social Skills: What skills to teach and how to teach them. Intervention in School and Clinic, 35(1), 29-33. https://doi.org/10.1177/105345129903500105

37. Greene, J. C. (2007). Mixed methods in social inquiry (Vol. 9). John Wiley \& Sons. 
38. Greene, S. M., Reid, R. J., \& Larson, E. B. (2012). Implementing the learning health system: from concept to action. Annals of internal medicine, 157(3), 207-210. https://doi.org/10.7326/0003-4819-157-3-201208070-00012

39. Hattie, J. \& Timperley, H. (2007). The power of feedback. Review of Educational Research, 77(1), 81-112. https://doi.org/10.3102/003465430298487

40. Hattie, J. (2003). Teachers Make a Difference: What is the research evidence? Retrieved from Education and Social Work: http://start.sd34.bc.ca/innovation/wp-content/uploads/2014/01/Hattie TeachersMakeADifference.pdf

41. Hendrawati, E. \& Muhlisin, M. (2018). The effect of cooperative learning type terror cards and nightmare cards towards the eleventh-grade students` speaking. Journal of Languages and Language Teaching, 6(1), 51-60. https://doi.org/10.33394/jollt.v6i1.813

42. Herrmann, K. J. (2013). The impact of cooperative learning on student engagement: Results from an intervention. Active learning in higher education, 14(3), 175-187. 187. https://doi.org/10.1177/1469787413498035

43. Heyes, J. (2013). Flexicurity in crisis: European labor market policies in a time of austerity. European Journal of Industrial Relations, 19(1), 71-86. https://doi.org/10.1177/0959680112474749

44. Hopper, E. (2015). Individualist or collectivist? How culture influences behavior. Retrieved from healthypsych.com: http://healthypsych.com/

45. Hu, G., \& Choo, L. (2016). The impact of disciplinary background and teaching experience on the use of evaluative language in teacher feedback. Teachers and Teaching, 22(3), 329-349. https://doi.org/10.1080 /13540602.2015.1058591

46. Hyland, K. (2013). Student perceptions of hidden messages in teacher written feedback. Studies in Educational Evaluation, 39(3), 180-187. https://doi.org/10.1016/j.stueduc.2013.06.003

47. Hyland, K., \& Hyland, F. (2006). Interpersonal aspects of response: Constructing and interpreting teacher written feedback. Feedback in second language writing: Contexts and issues, 206-224. https://doi.org/10.101 7/CBO9781139524742.013

48. Inuwa, U., Abdullahb, Z., \& Hassanb, H. (2015). Effects of cooperative learning on secondary students' achievement in financial accounting. (ICAS), International Conference on Accounting Studies.

49. Ismail, N., Maulan, S., \& Hassan, N. (2008). The impact of teacher feedback on ESL students' writing performance. Jurnal Akademik UiTM Johor, 8(1), 45-54.

50. Jan, K. (2013). Perceptions of private secondary school teachers in Pakistan regarding the effects of studentcentered approach on the abilities of their students. International Journal of Scientific \& Engineering Research, 4(2), 01-05.

51. Johnson, D. W., \& Johnson, F. P. (2009). Joining together: Group theory and group skills (Vol. 10). Boston: MA: Allyn \& Bacon.

52. Johnson, D. W., Holubec, E. J., \& Johnson, R. (1998). Advanced cooperative learning. Edina, MN: Interaction Book Company.

53. Johnson, R. B., \& Onwuegbuzie, A. J. (2004). Mixed methods research: A research paradigm whose time has come. Educational researcher, 33(7), 14-26. https://doi.org/10.3102/0013189X033007014

54. Jolliffe, W. (2015). Bridging the gap: teachers cooperating to implement cooperative learning. Education 313, 43(1), 70-82. https://doi.org/10.1080/03004279.2015.961719

55. Karali, Y., \& Aydemir, H. (2018). The Effect of Cooperative Learning on the Academic Achievement and Attitude of Students in Mathematics Class. Educational Research and Reviews, 13(21), 712-722. https://doi.org/10.5897/ERR2018.3636

56. Kaufman, D., Sutow, E., \& Dunn, K. (1997). Three approaches to cooperative learning in higher education. Canadian Journal of Higher Education, 27, 37-66. https://doi.org/10.47678/cjhe.v27i2/3.183303

57. Korkmaz, ö., \& Oztürk, Ç. (2020). The effect of gamification activities on students' academic achievements in social studies course, attitudes towards the course and cooperative learning skills. Participatory Educational Research, 7(1), 1-15. https://doi.org/10.17275/per.14.16.2.1

58. Kyndt, E., Raes, E., Lismont, B., Timmers, F., Cascallar, E., \& Dochy, F. (2013). A meta-analysis of the effects of face-to-face cooperative learning. Do recent studies falsify or verify earlier findings? Educational Research Review, 10, 133-149. https://doi.org/10.1016/j.edurev.2013.02.002

59. Laryea, S. (2013). Feedback provision and use in teaching and learning: a case study. Education+ Training, 55(7), 665-680. https://doi.org/10.1108/ET-06-2012-0071

60. Lau, P., Kwong, T., Chong, K., \& Wong, E. (2013). Developing students' teamwork skills in a cooperative learning project. International Journal for Lesson and Learning Studies, 3(1), 80-99. https://doi.org/10.1108/IJLLS-032013-0018

61. Lipnevich, A. A., \& Smith, J. K. (2008). Response to assessment feedback: The effects of grades, praise, and source of information. ETS Research Report Series, 2008(1), i-57. https://doi.org/10.1002/j.2333-8504.2008.tb02116.x 
62. Loh, R. C. Y., \& Ang, C. S. (2020). Unravelling Cooperative Learning in Higher Education: A Review of Research. Research in Social Sciences and Technology, 5(2), 22-39. https://doi.org/10.46303/ressat.05.02.2

63. Makini, V. S., Barasa, F. S., \& Chemwei, B. (2020). Effect of Cooperative Learning Approach on Students' Academic Achievement in English in Co-Educational Public Secondary Schools, Nakuru County, Kenya.

64. Martínez Lirola, M. (2016). A proposal to combine cooperative learning and peace education in a foreign language subject.Journal of Global Research in Education and Social Science, 5(2),102-111

65. Mashhadi, H., \& Gazorkhani, A. M. (2015). Effectiveness of cooperative learning (participation) method in academic achievement of students in teacher training centers. Journal of Social Issues \& Humanities, 3(5), 39-55.

66. Molin, F., Haelermans, C., Cabus, S., \& Groot, W. (2020). The effect of feedback on a metacognition-a randomized experiment using polling technology. Computers \& Education, 152, 103885. https://doi.org/10.1016/j.com edu.2020.103885

67. Motaei, B. (2014). On the effect of cooperative learning on general English achievement of Kermanshah Islamic Azad University students. Procedia-Social and Behavioral Sciences, 98, 1249-1254. https://doi.org/10.1016/j sbspro.2014.03.540

68. Najmonnisa \& Haroon, M. Z. (2014). Perspectives of primary school teachers regarding effectiveness of cooperative learning: A descriptive study. Journal of Education and Social Sciences, 2(1), 95-108.

69. Najmonnisa. (2013). A readiness study of cooperative learning. Karachi, Pakistan: Unpublished Ph.D. dissertation.

70. Nguyen, P. M., Elliott, J. G., Terlouw, C., \& Pilot, A. (2009). Neocolonialism in education: Cooperative learning in an Asian context. Comparative education, 45(1), 109-130. https://doi.org/10.1080/03050060802661428

71. Nicol, D. \& Macfarlane-Dick, D. (2006). Formative assessment and self-regulated learning: A model and seven principles of good feedback practice. Studies in Higher Education, 31(12), 199-218. https://doi.org/10.1080 103075070600572090

72. Ning, H., \& Hornby, G. (2014). The impact of cooperative learning on tertiary EFL learners' motivation. Educational review, 66(1), 108-124. https://doi.org/10.1080/00131911.2013.853169

73. Novitasari, F., \& Ardi, P. (2016). Developing a teaching methodology of translation course: A cooperative learning model for English department students. Indonesian Journal of English Language Studies (ILS), 2(1), 76-90.

74. Novitasari, F., \& Ardi, P. (2017). Developing a teaching methodology of translation course: A cooperative learning model for English department students. Indonesian Journal of English Language Studies (ILS), 2(1), 15.

75. Nunez, J. C., Suárez, N., Rosário, P., Vallejo, G., Cerezo, R., \& Valle, A. (2015). Teachers' feedback on homework, homework-related behaviors, and academic achievement. the Journal of Educational research, 108(3), 204-216. https://doi.org/10.1080/00220671.2013.878298

76. Orrell, J. (2006). Feedback on learning achievement: Rhetoric and reality. Teaching in Higher Education, 11(4), 441-456. https://doi.org/10.1080/13562510600874235

77. Ovando, M. N. (1994). Constructive feedback: A key to successful teaching and learning. International Journal of Educational Management, 8(6), 19-22. https://doi.org/10.1108/09513549410069185

78. Palincsar, A. S. (1998). Social constructivist perspectives on teaching and learning. Annual review of psychology, 49, 345-375. https://doi.org/10.1146/annurev.psych.49.1.345

79. Paulus, T. M. (1999). The effect of peer and teacher feedback on student writing. Journal of Second Language Writing, 8(3), 265-289. https://doi.org/10.1016/S1060-3743(99)80117-9

80. Pekrun, R., Cusack, A., Murayama, K., Elliot, A. J., \& Thomas, K. (2014). The power of anticipated feedback: Effects on students' achievement goals and achievement emotions. Learning and Instruction, 29, 115-124. https://doi.org/10.1016/j.learninstruc.2013.09.002

81. Perry, B., Geoghegan, N., Owens, K. \& Howe, P. (1995). Cooperative learning and social constructivism in mathematics education. Retrieved 02 24, 2016, from http://www.merga.net.au/document s/RP_Perry_Geoghega n_Owens Howe 1995.pdf

82. Phiwpong, N., \& Dennis, N. K. (2016). Using cooperative learning activities to enhance fifth-grade students' reading comprehension skills. International Journal of Research-Granthaalayah,4(1), 146-152. https://doi.org/10.2 z9121/granthaalayah.v4.i1.2016.2853

83. Pinger, P., Rakoczy, K., Besser, M., \& Klieme, E. (2018). Implementation of formative assessment-effects of quality of program delivery on students' mathematics achievement and interest. Assessment in Education: Principles, Policy \& Practice, 25(2), 160-182. https://doi.org/10.1080/0969594X.2016.1170665

84. Preacher, K. J., \& Hayes, A. F. (2004). SPSS and SAS procedures for estimating indirect effects in simple mediation models. Behavior research methods, instruments, \& computers, 36(4), 717-731. https://doi.org/10.375 $\underline{8 / \mathrm{BF} 03206553}$

85. Premo, J., Cavagnetto, A., Davis, W. B., \& Brickman, P. (2018). Promoting Collaborative Classrooms: The Impacts of Interdependent Cooperative Learning on Undergraduate Interactions and Achievement. CBE-Life Sciences Education, 17(2), ar32, 1-16. https://doi.org/10.1187/cbe.17-08-0176 
86. Price, M., Handley, K., \& Millar, J. (2011). Feedback: Focusing attention on engagement. Studies in higher education, 36(8), 879-896. https://doi.org/10.1080/03075079.2010.483513

87. Ramaprasad, A. (1983). On the definition of feedback. Behavioral science, 28(1), 4-13. https://doi.org/10. 1002/bs.3830280103

88. Reza, K. M., Abozar, H. R., Ali, E. N., \& Akba, H. (2013, winter). The impact of cooperative learning on students science academic achievement and test anxiety. Journal of Educational Innovations, 11(44), 83-98.

89. Rodzalan, S. A., \& Saat, M. M. (2012). The effects of industrial training on students' generic skills development. Procedia-social and behavioral sciences, 56, 357-368. https://doi.org/10.1016/j.sbspro.2012.09.664

90. Ross, J. A. (1995). Effects of feedback on student behavior in cooperative learning groups in a grade 7 math class. The Elementary School Journal, 96(2), 125-143. https://doi.org/10.1086/461818

91. Ruegg, R. (2016). The effect of assessment of process after receiving teacher feedback. Assessment \& Evaluation in Higher Education, 41(2), 199-212. https://doi.org/10.1080/02602938.2014.998168

92. Sajjad, S. (n.d.). Effective teaching methods at higher education level. Retrieved June 3, 2011, from http://www.wfate.org: http://www.wfate.org/papers/Research_paper_Teaching_methods.pdf.

93. Sarwar, Z. (2001, Autumn). Innovations in large classes in Pakistan. TESOLQuarterly, 35(3), 497-500. Retrieved from http://innovationinteaching.org/: https://doi.org/10.2307/3588033

94. Sadler, D. R. (2013). Opening up feedback. Reconceptualising feedback in higher education: Developing dialogue with students, 1, 54-63.

95. Sharan, Y. (2015). Meaningful learning in the cooperative classroom. Education 3-13: International Journal of Primary, Elementary and Early Years Education, 43(1), 83-94. https://doi.org/10.1080/03004279.2015.961723

96. Shah, S. A. M., \& Amjad, S. (2011). Cultural diversity in Pakistan: national vs provincial. Mediterranean Journal of Social Sciences, 2(2), 331-331.

97. Sekaran, U. (2006). Research Methods for Business: Metodologi Penelitian Untuk Bisnis. Buku 2.

98. Shute, V. J. (2008). Focus on formative feedback. Review of Educational Research, 78(1), 153-189. https://doi.org/10.3102/0034654307313795

99. Shute, V. J., \& Kim, Y. J. (2014). Formative and stealth assessment. In Handbook of research on educational communications and technology (pp. 311-321). Springer, New York, NY. https://doi.org/10.1007/978-1-4614-3185$\underline{5 \_25}$

100.Sturz, D. L., Kleiner, B. H., \& Fernandez, A. (2005). Effective management of cultural diversity in a classroom setting. Equal opportunities international.Vol. 24 No. 5/6, pp. 57-64. https://doi.org/10.1108/02610150510788169

101.Samuels, H. (2013). 20th-Century Humanism and 21st-Century Technology: A Match Made in Cyberspace. In English Teaching Forum (Vol. 51, No. 3, p. 2). US Department of State. Bureau of Educational and Cultural Affairs, Office of English Language Programs, SA-5, 2200 C Street NW 4th Floor, Washington, DC 20037.

102.Siddique, G. K., Yasmin, T., Nadeem, M., \& Farooq, S. (2020). Role of Cooperative Learning in Improving Language Proficiency and Academic Achievement in English of Elementary Students: An Experimental Study. Journal of Business and Social Review in Emerging Economies, 6(3), 1159-1164. https://doi.org/10.26710/jbsee.v6i3.1385

103.Slavin, R. E. (2015). Cooperative learning in elementary schools. Education 3-13: International Journal of Primary, Elementary and Early Years Education, 43(1), 5-14. https://doi.org/10.1080/03004279.2015.963370

104.Synnott, C. K. (2016). Guides to reduce social loafing in group projects: Faculty development. Journal of Higher Education Management, 31(1).

105.Sultana, M., \& Zaki, S. (2015). Proposing Project Based Learning as an alternative to traditional ELT pedagogy at public colleges in Pakistan. International Journal for Lesson and Learning Studies. https://doi.org/10.1108/IJLLS09-2013-0049

106.Tan, I. G. C., Sharan, S., \& Lee, C. K. E. (2007). Group investigation effects on achievement, motivation, and perceptions of students in Singapore. The Journal of Educational Research, 100(3), 142-154. https://doi.org/ 10.3200/JOER.100.3.142-154

107.Thanh-Pham, T., Gilles, R., \& Renshaw, P. (2008). Cooperative learning (CL) and academic achievement of Asian students: A true story. International Education Studies, 1(3), 82-88. https://doi.org/10.5539/ies.v1n3p82

108.Tomasello, M. (2009). The cultural origins of human cognition. Harvard university press. https://doi.org/1 $0.2307 / j . c t v j s f 4 j \mathrm{jc}$

109.Torres, J. T., Strong, Z. H., \& Adesope, O. O. (2020). Reflection through assessment: A systematic narrative review of teacher feedback and student self-perception. Studies in Educational Evaluation, 64, 100814. https://doi.org/10.1016/j.stueduc.2019.100814

110.Tran, V. D., \& Lewis, R. (2012). The Effects of Jigsaw Learning on Students' Attitudes in a Vietnamese Higher Education Classroom. International Journal of Higher Education, 1(2), 9-20. https://doi.org/10.5430/ijhe.v1n2p9 
111.Tucker, P. D. \& Stronge, J. H. (2005). The Power of an Effective Teacher and Why We Should Assess It. In P. D. Tucker, Linking Teacher Evaluation and Student Learning. ASCD.

112.Van den Bergh, L., Ros, A., \& Beijaard, D. (2013). Feedback during active learning: elementary school teachers' beliefs and perceived problems. Educational Studies, 39(4), 418-430. https://doi.org/10.1080/030556 98.2013.767188

113.Vance, K., Konak, A., Kulturel-Konak, S., Kremer, G. O., \& Esparragoza, I. (2015, April). Teamwork efficacy, attitudes, and interest: Insights on their relationships. In Proceedings of ASEE Mid-Atlantic Section Spring 2015 Conference, Villanova University, PA (pp. 1-13).

114.Värlander, S. (2008). The role of students' emotions in formal feedback situations. Teaching in higher education, 13(2), 145-156. https://doi.org/10.1080/13562510801923195

115.Vygotsky, L. S., van der Veer, R. E., Valsiner, J. E., \& Prout, T. T. (1994). The Vygotsky reader. Basil Blackwell.

116.Vega-Vaca, M., \& Hederich-Martnez, C. (2015). The impact of a cooperative learning program on the academic achievement in mathematics and language in fourth-grade students and its relation to cognitive style. Journal of New Approaches in Educational Research (NAER Journal), 4(2), 84-90. https://doi.org/10.7821/naer.2015.7.124

117.Waksman, S. A. (1985). The development and psychometric properties of a rating scale for children's social skills. Journal of Psychoeducational Assessment, 3(2), 111-121. https://doi.org/10.1177/073428298500300202

118.Webb, N. M. (2009). The teacher's role in promoting collaborative dialogue in the classroom. British Journal of Educational Psychology, 79(1), 1-28. https://doi.org/10.1348/000709908X380772

119. White, S. (2008). Using Action Research-To Gauge the Quality of Feedback Given to Student Teachers While on Professional Teaching Practice. Qualitative Research Journal, 8(2), 124-133. https://doi.org/10.3316/QRJ0802124

120. Yoke, S. K., Rajendran, C. B., Sain, N., Kamaludin, P. N. H., Nawi, S. M., \& Yusof, S. (2013). The Use of Online Corrective Feedback in Academic Writing by L1 Malay Learners. English Language Teaching, 6(12), 175-180. https://doi.org/10.5539/elt.v6n12p175

121.Zhu, M., Liu, O. L., \& Lee, H. S. (2020). The effect of automated feedback on revision behavior and learning gains in formative assessment of scientific argument writing. Computers \& Education, 143, 103668. https://doi.org/10. 1016/j.compedu.2019.103668 